\title{
Storytelling and Puppetry
}

Susan Fulcher

Follow this and additional works at: https://opencommons.uconn.edu/ballinst_catalogues

Part of the African American Studies Commons, Africana Studies Commons, and the Other Theatre and Performance Studies Commons

\section{Recommended Citation}

Fulcher, Susan, "Storytelling and Puppetry" (2019). Living Objects: African American Puppetry Essays. 10. https://opencommons.uconn.edu/ballinst_catalogues/10 


\section{Storytelling and Puppetry}

by Susan Fulcher

I am a Children's Library Assistant at the Matteson Area Public Library District in Matteson, Illinois. I am African American, and so is seventy-five percent of the Matteson community. For the last four years at the Matteson Library, I have been running a program called “The Junior Puppeteers," where professional puppeteer Dave Herzog and I teach fourth through sixth graders how to build and perform with puppets.

Storytelling with kids as puppeteers is very different from storytelling with adults as puppeteers. When you are the puppeteer, you can tell or perform a story any way you like. You can tell the story the way it was written, or you can add something, like a new character, or a different location. You can also delete a character or a location, and all is well and good. But with upper-elementary students as the puppeteers, I have found that they want to be part of the whole process, including writing the script. They want the story to be relevant to them and to what's important to them. So during our program in Fall 2018, in which we performed Stone Soup, we let them take the lead and it worked out nicely.

Dave Herzog and I first talked to the kids about the classic versions of the story. We told the story from two different perspectives. The first was the French version, where three soldiers came to the village in search of food. When they didn't find any, they started making stone soup. The second was the Portuguese version, where a peasant came to the village in search of food. We let the kids know that we were performing the Portuguese version. We needed someone to play the peasant, a cobbler, a baker, the mayor, a Mrs. Snooty-Pants, etc. Well, the kids didn't like those choices of characters, but Dave and I agreed that we still needed certain characters - the mayor, Mrs. Snooty-Pants, and the peasant - and a little kid to help move the story along. So, we figured since this was our first performance, we would let them help tell the story by designing the puppets their own way. The kids decided that the villagers would be superheroes. The Batman glove puppet on display in the Living Objects: African American 
Puppetry exhibition at the Ballard Institute and Museum of Puppetry was one of those villagers in the show.

Once we decided upon the characters and wrote the script, then we built the puppets. Dave taught the kids how to mold clay into the shape of a face. Then the kids put papier-mâché over the clay. Once it was dry, Dave and I cut the heads in half, scooped out the clay, then hot-glued the head back together. The kids then painted the heads and added facial features. Dave and I sewed the puppets' bodies and the kids decorated them. Once complete, rehearsals began. After six weeks of building and rehearsing, the kids performed for their parents. You can find a copy of their show on YouTube at https://www.youtube.com/watch?v=Ig9JicFpEuA.

Dave and I found out that at the end of the day, giving the kids the opportunity to provide input regarding every aspect of a puppet performance encouraged them to continue coming to the program. 